INGURUAK [71] | $2021 \mid 56-78$

http://dx.doi.org/10.18543/inguruak-71-2021-art04

ISSN 0214-7912

\title{
Mugak, harresiak eta giza mugikortasuna: marko teoriko-normatiboa ${ }^{\&}$ Borders, walls and human mobility: a theoretical and normative framework
}

\author{
Borja Niño Arnaiz* \\ Universidad Rey Juan Carlos
}

\begin{abstract}
LABURPENA: Lan honen helburua mugei buruzko marko teoriko-normatibo bat eraikitzea da, nazioarteko migrazioen egungo testuinguruan. Artikuluaren lehen zatian kontzeptu ezberdinen eta mugen bilakaera historikoaren errepaso labur bat egingo da, horrez gain muga-erregimen garaikidearen joerak eta arazoak azpimarratuko dira. Artikuluaren tesi nagusietako bat da muga kontzeptu funtzionala dela, eta, beraz, ezin dela ulertu betetzen dituen funtzioak kontuan hartu gabe: juridiko-politikoa, sinbolikoa eta fluxuen erregulazioa. Hauei laugarren bat gehituko zaie: aukerak espazialki xedatzea. Azken hau tradizio kosmopolitikoarekin bat dator, eta hain arbitrarioa eta moralki garrantzirik ez duen baina pertsonen bizitzan ondorio bidegabeak dituen jazoera bat - mugen trazadura - salatzea du helburu. Artikuluaren bigarren zatian, beraz, mugak ikuspegi honetatik jorratuko dira, muga irekien proposamena aztertuz eta hauek birpentsatzeko (eta birfuntzionalizatzeko) beharra aldarrikatuz, justizia globalaren eskakizunekin koherentea izan daitezen.
\end{abstract}

Hitz gakoak: mugak, migrazioak, justizia globala, muga irekiak, kosmopolitismoa.

ABSTRACT: This work aims to contribute to the construction of a theoretical-normative framework of borders in the current context of international migrations. The first part of the article is devoted to the review of the different concepts and the historical evolution of borders, as well as to problematize the contemporary border regime. One of the main theses of the article is that the border is a functional concept, and as such, it cannot be understood apart from the main three functions it performs: legal-political, symbolic and flow regulation. A fourth function will be added: to spatially circumscribe opportunities, raised by cosmopolitan concerns about the unjust consequences that such an arbitrary and morally irrelevant fact as the drawing of borders has on people's lives. The second part of the article is devoted precisely to the analysis of borders from the perspective of global justice. To this end, the proposal of open borders is examined and the need to rethink them from this perspective is asserted.

Keywords: borders, migrations, global justice, open borders, cosmopolitanism.

\footnotetext{
\& Lan hau JAE Intro (2020) bekaren laguntzaz egin da, CSIC-eko Filosofia Institutuan, Juan Carlos Velasco-ren tutoretzapean.
}

\footnotetext{
* Harremanetan jartzeko/Correspondence to: Borja Niño Arnaiz. Consejo Superior de Investigaciones Científicas (CSIC) - b.nino.2018@alumnos.urjc.es https://orcid.org/0000-0001-9585-2473

Nola aipatu/How to cite: Niño Arnaiz, Borja (2021). "Mugak, harresiak eta giza mugikortasuna: marko teoriko-normatiboa»; Inguruak, 71, 56-78. (http://dx.doi.org/10.18543/inguruak-71-2021-art04).

Jasoa/Received: 2021 uztaila 28; Onartua/Final version: 2021 azaroa 10.

ISSN 0214-7912 / (c) 2021 UPV/EHU
}

(c) (9) Lan hau Creative Commons Aitortu-EzKomertziala-LanEratorririk 4.0 Nazioartekoa

(c) lizentzia baten mende dago 


\section{1. "MUGA» KONTZEPTUA MUGATUZ}

Lan honen helburua mugei buruzko marko teoriko-normatiboa eraikitzea da, nazioarteko migrazioen egungo testuinguruan. Baina aurretik bi argibide eman behar ditugu. Lehenengoa, artikulu honek muga mota oso zehatz bat du xede: muga politikoak (lurraldeedo estatu-mugak ere deituak). Muga politikoen dimentsio ugariak ikusiko baditugu ere, ez ditugu bestelako mugarik aipatuko, hala nola zientziaren edo ezagutzaren mugak, bizitzaren eta heriotzaren arteko muga, eta abar ${ }^{1}$. Bigarrena, lanaren izaera edo hurbilpen bikoitzarekin du zerikusia; izan ere, izenburuak zehazten duen bezala, marko teoriko zein normatibo bat eraikitzea du helburu. Testuaren lehen zatian, ikuspegi teoriko-deskriptibo batetik, kontzeptu nagusien definizioa eta bereizketa (1. atala), mugen bilakaera historikoa (2. atala), muga-erregimen garaikidearen azterketa (3. atala) eta horien funtzioen edo dimentsioen deskribapena (4. atala) egiten da. Lanaren bigarren zatian, mugen ikuskera honek dakarren arazoak eta inplikazio moralak eztabaidatzen dira ikuspegi etiko eta normatibo batetik. Tradizio kosmopolita eta justizia globalaren teoriara joz, muga irekien proposamena aztertzen da (5. atala), eta mugak ikuspegi horretatik birpentsatzeko eta birfuntzionalizatzeko beharra aldarrikatzen da (6. atala).

"Muga» kontzeptua definitzea ez da zeregin erraza. Arrazoi nagusietako bat "definitu” aditzaren esanahia bera da. Étienne Balibarrek (2005: 77-78) gogorarazten digun bezala, definitzea mugak ezartzea, mugatzea baino ez da; hortaz, "gurpil zoro batean sartzeko arriskua daukagu, mugen irudikapena definizio ororen baldintza baita». Beste zailtasunetako bat muga eta gizarteen arteko elkar eratze-harremana da: mugak gizarte ororen baldintza dira, baina aldi berean mugak giza produktuak dira (Nail, 2016: 4). Beraz, gizarteak mugatutako lurralde-elkarte, elkarte politiko, juridiko edo ekonomiko gisa ulertzen baditugu eta mugak gizarte horiek sortzen dituzten zatiketak badira, nola mugatu (eta sortu) ziren lehenik eta behin?

Baina, gogoeta metalinguistiko eta metafisikoak alde batera utzita, mugak definitzeko zailtasuna haien izaera zirkunstantzial eta kontingentean datza —aldi eta toki bakoitzeko praktika sozial, politiko eta espazialen produktu gisa-, eta baita haien polisemia eta aldaberatasunean ere, haien kontraesanak ez aipatzeagatik. Mugen konplexutasuna haien esanahi, funtzio eta dimentsio ugaritan ikus dezakegu (ikus azpiko taula). Bestela esanda, muga kontzeptu polisemikoa, multifuntzionala eta multidimentsionala da.

Polisemia hori terminoaren anbibalentzian eta esanahi desberdinetan islatzen da: alde batetik, konstruktu soziala² — eta, beraz, kontingentea eta artifiziala— da, baina bestetik, naturaltzat, emantzat eta aldaezintzat hartzen da; gertakari arbitrarioa baina izugarri fun-

\footnotetext{
1 Beste zentzu, esanahi eta muga mota batzuetarako, ikus Zapata-Barrero (2012: 45-47), Fernandez-Carrión (2008: 5-17) edota Furedi (2020).

2 Mugak ez dira soilik produktu edo konstruktu sozialak; aldi berean performazio gailu indartsuak ere badira, gizarte-eremua eratzen dutenak eta «proiektatzen diren geografiak aldatzen dituztenak» (Mendiola, 2019:41).
} 
tzionala; segurtasunak (edo segurtasunik ezak) sortzen duen gailu sekuritarioa (Mendiola, 2018: 25); igarobide eta elkargunea batzuetan eta tentsio edo konfrontazio eremua bestetan; batzuen opulentziaren eta beste batzuen bazterketaren sinboloa; gainbeheran dagoen estatu subiranotasunaren berrespen- eta botere-egintza; blokeatzen eta atxikitzen duen artefaktu mugikorra; mugarik ez duela dirudien muga; errealitate birtualeko teknologia, izaera «espektrala» (Mendiola, 2018: 26) eta ia nonahikoa, baina materializazio zehatzak dituena (Mendiola, 2018: 21), dela lurrazalean, dela migratzaileen gorputzetan. Régis Debray-ren (2016: 32) hitzetan: «bakea zigilatu eta gerra pizten du. Apaldu eta askatzen du. Banandu eta elkartzen du». Aldakortasun edo anbibalentzia hori ez da ustekabekoa, honen bi rol nagusiekin loturikoa baizik: lotunea edo banalerro gisa jardutea.

1. taula. Mugen polisemia eta anbibalentzia

\begin{tabular}{|c|c|}
\hline $\begin{array}{c}\text { Konstruktu soziala: } \\
\text { kontingentea eta artifiziala }\end{array}$ & $\begin{array}{c}\text { Naturalizatua: } \\
\text { politika aurrekoa, emana eta aldaezina }\end{array}$ \\
\hline (Moralki) arbitrarioa & Funtzionala \\
\hline $\begin{array}{l}\text { Gailu sekuritarioa, } \\
\text { arriskuaren logika }\end{array}$ & $\begin{array}{c}\text { Gailu beliko-militarra, zeharka indarkeria } \\
\text { eta segurtasunik eza sortzen duena }\end{array}$ \\
\hline Igarobide- eta kontaktu-eremua & Tentsio- edo liskar-eremua \\
\hline $\begin{array}{c}\text { Muga mugikorra (shifting border), } \\
\text { fluxuen kanalizazioa }\end{array}$ & $\begin{array}{l}\text { Fluxuen blokeoa } \\
\text { eta atxikipena }\end{array}$ \\
\hline Oparotasunaren oroitarria & Bazterkeria-ikurra \\
\hline Demarkazio-linea finkoa & Lerro mugikorra eta ia nonahikoa \\
\hline $\begin{array}{l}\text { (Smart border-aren) izaera birtuala } \\
\text { eta presentzia «espektrala» }\end{array}$ & $\begin{array}{c}\text { Lurraldean gauzatua eta migratzaileetan } \\
\text { korporeizatua }\end{array}$ \\
\hline Lokarria edo lotura-puntua & Banantze-lerroa edo -hesia \\
\hline
\end{tabular}

Iturria: egileak landua.

Mugen polisemiari buruz hitz egitea haren funtzio-aniztasunari buruz hitz egitearen sinonimo da. Aurrerago ikusiko dugun bezala, mugen esanahia horiek betetzen dituzten funtzioekin zuzenki lotuta dago, eta, beraz, ezin dugu bata bestea barik ulertu. Mugek askotariko funtzioak betetzen dituzte, garai eta leku bakoitzeko beharrizan sozialei eta helburu politikoei erantzuteko. Hala ere, gaur egun lau funtzio nagusi bereiz ditzakegu: (1) lurralde-mugaketaren funtzio juridiko-politiko tradizionala; (2) funtzio sinboliko-analitikoa; (3) fluxuen erregulazio funtzioa (ondasun-, pertsona- eta kapital-fluxuak); eta, aurrekoarekin hertsiki lotuta, (4) aukerak espazioan mugatzea eta aberastasunaren banaketa desorekatua finkatu eta iraunaraztea. Eginkizun horiek aurrerago garatuko dira.

Terminoa ulertzeko, aldez aurretik bi argibide eman behar dira: lehenengoa mugak harresiengandik bereizteko beharrari dagokio, haien iragankortasuna edo iragangaiztasunaren arabera (Velasco, 2020a: 39). Biek muga bat izendatzen badute ere, harresiek 
dute bakarrik komunikazioa eta zirkulazioa eragoztea funtzio nagusitzat. Aitzitik, mugak mintz gisa ulertu beharko lirateke, hau da, iragazkorrak baina aldi berean egonkorrak, edo hobeto, proxy gisa, «sarrera kontrolatu, trafikoa erregistratu, trafiko-mota jakin batzuk murriztu eta komunikazioen errendimendua hobetzeko funtzioak» garatzen dituena (San Martín Segura, 2019: 28).

Bigarren bereizketa muga eta mugaldeari dagokio. Muga (boundary edo border) estatu baten eskumenaren amaiera adierazten duen eta erakunde politikoak mugatzea helburu duen mapa baten gaineko lerroa da (Cairo Carou, 2001: 33). Mugalde (boundary) kontzeptuak, berriz, mugatik hurbil dagoen eremuari egiten dio erreferentzia, eta mugaren presentziaren mende dago. Boundary-ren ordez borderland kontzeptua gero eta gehiago erabiltzen da (Newman, 2002: 126). Azken honek mugaren alde batean eta bestean bizi diren komunitateen artean sortzen diren praktika eta gizarte-harremanen multzoari egiten dio erreferentzia. Eskualde horiek trantsizio-eremuak dira askotan, desberdintasunak pixkanaka desegiten diren tokiak eta hibridazio kulturalak sor ditzaketenak (Newman, 2006: 151).

Ignacio Mendiolak (2018: 14) nahiago du frontis («kanpoaldea erakusten duen eta barrualdea ezkutatzen duen lerro baten kanpoko proiekzio arkitektonikoa») eta limes («lotzen eta bereizten duen eremu interstizial bat, espazioari finkapen zehatzik izendatzen ez duena, ibilbide bat baizik») kontzeptuak erabiltzea muga eta mugaldearen arteko ezberdintasuna azaltzeko. Laburbilduz, muga kontzeptuak espazio-banaketa eta jarraitutasunaren haustura bortitza adierazten duen bitartean, mugalde kontzeptuak «giza, gizarte, ekonomia eta kulturaren jarraitutasuna» aditzera ematen du (Aguelo-Navarro eta Granero-Sánchez, 2017: 63).

\section{KONTZEPTUAREN BILAKAERA HISTORIKOA}

Mugen eta mugaldeen arteko bereizketa hori oso erabilgarria da mugen bilakaera azaltzeko: «estatu modernoetan muga lineala bereizgarri den bitartean, estatu tradizionaletan mugaren ideiak eremu bati [mugaldea] egiten zion erreferentzia» (Cairo Carou, 2001: 34). Lurraldeko mugak mapa batean dauden lerro finko gisa (lines in the sand) ulertzeko modu hori ez zen posible izango kartografia modernoaren garapenik gabe, horrek aukera eman baitzuen lurraren ezagutza zehatzago bat izateko (Fernández-Jardón, d.g.: 11-12).

Hala eta guztiz ere, aurrerago argudiatuko den bezala, badirudi estatu modernoen mugen bereizgarri den linealtasunerako berezko joera hori lehengoratzen ari dela, aurrekoaren antzekoa zen egoerara itzuliz (de jure ez bada, de facto), mugek lurraldean proiekzio eta sakontasun handiagoa zuten garaira. Aditu askok diotenez (Shachar, 2020: 5-6), mugak lurraldetik kanpo hedatzen ari dira, baita barrualderantz ere. Muga mugikorra edo aldakorra (shifting border) edo, modu argiagoan, muga «erretraktila» esaten zaio horri. 
Lurralde-mugapeneko erakunde gisa, mugak ez dira beti araua izan. Lehenengo talde nomaden artean jabetza eta lurraldetasunari buruzko nozio batzuk bazeuden ere (Diener eta Hagen, 2012: 27), lehen mugak komunitate sedentarioen agerpenarekin sortu ziren. Hauekin batera lehen estatu egiturak agertu ziren, mugapen politikoari eta lurraldearen kontrolari buruzko kezkekin (Graziano, 2018: 11). Hala ere, hirien eta ondorengo inperio handien defentsa ez zen egitura fisiko sendoetan eta lerro garbietan oinarritzen (salbuespen batzuk bazeuden ere), tarteko trantsizio-eremu handietan (buffer zones) eta orografiak emandako babes naturaleetan baizik.

Izan ere, Erromatar Inperioa mendebaldean desintegratu ondorengo milurtekoan, Europako mugek izaera oso ezegonkorra zuten. Izaera irregular hau Feudalismoan ematen da aditzera bete-betean: garai hartan muga politikoek, herri edo komunitate baten lurraldea mugatu baino gehiago, jaunen eragin-eremuak eta menpekoek hauekiko zuten leialtasunaren norainokoa adierazten zuten (Agnew, 1994: 60; Taylor, 1996: 37). Horrela, basailuak zenbait agintariren menpe egon zitezkeen, horien lurraldeak gainjarriz; eta agintari baten agindupeko lurrak bata bestearengandik fisikoki urrun kokatuta egon zitezkeen ere (Graziano 2018: 14).

Gaur ezagutzen ditugun mugak duela hiru mende eta erdi baino gehiagokoak dira; eta Estatu modernoaren sorrerari eta Westfaliako Bakean berretsitako subiranotasun-printzipioari estuki lotuta daude. Prozesu horretan, estatu batek bere aginpide esklusiboaz eremu geografiko jakin batean beste estatu batzuen interferentziarik gabe baliatzeko eskubidea ezarri zen. Horrek, nazionalismoaren agerpenarekin batera, mugei balio sinboliko bat eman zion. Horren ondorioz, mugak hizkuntza eta identitate komun bat partekatzen duten gizabanakoen multzo baten eremuaren seinale bihurtu ziren, baita kultura, historia, erlijio eta beste lotura batzuk ere - 'nazio’ gisa ezagutzen duguna.

Mugen westfaliar ideala, zatiketa zurrun eta iraunkorreko lerroetan oinarrituta, hainbesteraino heldu da, non mugak naturalizatu egin diren, emandakotzat eta aldaezintzat hartu baitira (Shachar, 2020: 17-18). Geografoek «lurralde-tranpa» (territorial trap) izendatutako ikuskera oker horrek ahaztera garamatza lurraldea eta mugak ez direla gertaera aurre-politiko eta objektiboak, etengabe aldatzen ari diren produktu soziopolitikoak baizik (Agnew, $1994)^{3}$.

Lehen Mundu Gerrara arte, Europako estatuek ez zituzten gaitasun tekniko eta burokratiko nahikoak garatu beren mugak eraginkortasunez kontrolatzeko (Sassen, 2013: 33). Ordura arte, «mugako kontrolak minimoak, prekarioak eta, nolanahi ere, horiek gauzatzeko gaitasun tekniko mugatuekiko proportzionalak ziren» (Velasco, 2021: 243).

\footnotetext{
${ }^{3}$ Muga aztertzeko joera berriek «zalantzan jarri dute lurralde-mugen estatus ontologikoa, mugak "material”, "natural” edo "saihestezintzat" jotzen dituen ikuskera, haien esanahia eta politikan duten eginkizuna finko egongo balitz bezala, zalantzan jarriz. Aldiz, enfasi berezia jartzen zaio mugak praktika sozial gisa tratatzeari» (Williams, 2006: 6). "Honek lurralde-mugak esklusiboak edo [...] nagusiki "naturalak" direla dioen ideia baztertzea eskatzen du, hau da, giza agentziatik aparte gertatzen direla» (Williams, 2006: 18).
} 
Globalizazio "neoliberalaren» aurrerapenarekin, subiranotasuna —eta, horrekin batera, mugak - zalantzan jarri dira. Gero eta integratuago eta konektatuago dagoen mundu honetan, kapital, ondasun eta informazioaren mugimendurako oztopoak desagertzen ari dira. Hori dela eta ez ziren gutxi izan Estatu-nazioen amaiera eta mugen desagerpena iragarri zutenak. Baina hauek, desagertzetik urrun, inoiz baino indar handiagoz itzuli dira, beren adierazle gorenean: horma eta harresi moduan. Kontraesan honi globalizazio «harresitua» (Aguelo-Navarro eta Granero-Sánchez, 2017: 64) edo «mugatua» (Velasco, 2016: 34) deitu zaio; izan ere, kapitalen eta salgaien mugimendurako oztopoak altxatzearekin batera, pertsonen mugimendu askerako oztopoak ugaritu egin dira.

Wendy Brown-en ustez (2015), estatuen subiranotasunaren gainbehera hori —edo, hobeto esanda, estatuarengandik aldentzea eta kapitala bezalako botere-gune berriak mendean jartzea- harresien egungo eraikuntza-frenesiaren atzean dago. Horiek, estatuaren subiranotasunaren indarraren berrespena baizik, gainbeheran dagoen subiranotasun baten eta globalizazioaren dinamikak gobernatzeko estatuen ezintasunaren sintomak izango lirateke.

\section{EGUNGO MUGA-ETA MIGRAZIO-ERREGIMENA}

Gaur egungo dinamika sozial eta ekonomikoak kontraesanez josita daude: alde batetik, eskualderik oparoenak ondasun, pertsona eta kapitalen mugikortasun handiago baterantz doaz, multinazionalek ia oztoporik gabe jarduten dute eta turista edo migratzaile kualifikatuek inoiz ez bezalako mugikortasuna dute; baina, beste alde batetik, harresiak eta burdin sareak altxatzen ari dira ${ }^{4}$, bai eta zaintza-dispositibo sofistikatuak hedatzen ere, segurtasunaren eta legez kanpoko immigrazioaren mesedetan. Horrek erakusten digu mugak ez direla gailu neutralak, diskriminatzaileak eta asimetrikoak baizik: subjektu/objektu mugikorraren izaeraren arabera hautatu eta iragazten dutenak. Mugek ez dute berdin funtzionatzen "gauzentzat» eta "pertsonentzat», eta azken horien artean ere ezberdintasun handiak daude. Mugak desberdin bizi (edo pairatzen) dira subjektuaren jatorriaren eta klase sozialaren arabera.

Gaur egungo migrazio-erregimenaren beste ezaugarrietako bat immigrazioa eta mugikortasuna segurtasunaren ikuspegitik tratatzea da, bereziki irailaren 11ko atentatuen ondorioz. Ikuspegi sekuritario honek immigrazioa «mehatxuaren eta arriskuaren erretorikatik» ulertzen du (Mendiola, 2019: 52). Migratzaileak segurtasun nazionalerako arriskutzat jotzen dira, eta terrorismoarekin eta delinkuentzia antolatuarekin lotzen dira. Horrela, migratzailea segurtasun nazionalaren aurkako mehatxuen talderik zabalenean (eta potentzialki arriskutsuenean) diluituta geratzen da. Ondorioz, «bazterketa eta desberdintasun

\footnotetext{
${ }^{4}$ Michel Foucher-en arabera (2012: 7), «1991tik [2012ra arte], nazioarteko muga 28.000 kilometro berri baino gehiago ezarri dira, beste 24.000 mugaketapean daude, eta iragarritako harresi, hesi eta barrera metaliko edo elektronikoen programak gauzatuko balira, $18.000 \mathrm{~km}$-tan zehar hedatuko lirateke».
} 
sozioekonomikoak kriminalitate-arazo kontsideratzen dira, eta ez arazo politiko; hartan, kode penaleko tresnak erabiltzen dira nagusiki etiologia sozial argiko arazoak konpontzen saiatzeko» (Velasco, 2020b: 167).

Politika honek funtsezko hainbat akats ditu: lehenengoa, immigrazio irregularra nazioarteko terrorismoarekin eta krimen antolatuarekin nahastean datza, gauza bera balira bezala, eta horrek neurri zakarrak hartzera darama, migrazioen azpian dauden kausa eta dinamika sozialetatik oso urrun daudenak. Bigarrena, immigrazio irregularraren aurkako borroka bitarteko gisa ulertzea da, hau da, ustezko segurtasun-arazoekin amaitzeko modu bat (ikuspegi sekuritario hutsetik), bere baitan helburu bihurtzeko. Hala, kolore desberdineko gobernuek immigrazio irregularraren aurkako borroka beren bandera bihurtu dute, propaganda-interes hutsek bultzatuta eta immigrazioaren gaia hauteskundeei begira errentagarri egiteko asmoz. Hirugarrenik, erakuste sekuritario horrek eskubide eta askatasunen murrizketak dakar etorkinei ez ezik, herritar guztiei ere. Azkenik, eta hori guztia gorabehera, "ez dago argi, trukean, segurtasun maila nabarmen igo denik» (Arango, 2011: 59) eta «ez dirudi sarrera irregularrak gutxiagotu direnik» (Arango, 2011: 57).

Horren guztiaren emaitza da mugak jada ez duela soilik mugako lerroan jarduten, espazioan eta denboran nonahiko ${ }^{5}$ bihurtuz. Alde batetik, hirugarren herrialdeak (jatorrizkoak eta igarotzekoak) azpikontratatuz eta kontrol-lanak sektore pribaturantz kanporatuz (adibidez, hegazkin-konpainietara), muga aurreratu egiten da denboran zein espazioan, gurutzatzeko unea eta tokia baino askoz lehenago. Bestalde, muga bidegurutzetik haratago luzatzen da, herrialdean barne-kontrolen eta migratzaileen inklusiorako oztopoen inposaketarekin. Horiei deitzen diegu barne-mugak: migratzaile «deserosoak» diziplinatzeko praktikei, «inklusio diferentziala» (Mezzadra eta Neilson, 2017: 186-196) eta eskubide eta prestazio sozialak eskuratzeko oztopo asimetrikoak ezartzen dituztenei.

Europar Batasunak «babes» armarri (edo kanporatze-sistema) konplexu bat eraiki du, hirugarren herrialdeekin akordioak sinatuz. Akordio horien helburua da, alde batetik, migrazio-fluxuak jatorrizko zein iragaitzazko herrialdeetan eustea, helmugara irits ez daitezen; eta, bestetik, Europara iritsi diren etorkinak hirugarren herrialdeetako errefuxiatu-esparruetan «birkokatzea». Garapenerako laguntzen, merkataritza-akordioen, bisaizapideen erraztasunen edo gaitasunen sustapenaren (errefuxiatu-esparruak eraikitzeko edo mugazainei ekipamendua emateko) truke, Europar Batasuna bere negoziazio-ahalmenaz baliatzen da giza eskubideen arloan zalantzazko bermeak dituzten herrialdeei lehoi-akordioak ezartzeko. Horrela, Europak eskuak garbitzen ditu haren migrazio-legeriak dakarren giza ondorioengatik (Amilhat Szary 2015: 53). Adibide berriena EBk eta Turkiak

\footnotetext{
${ }^{5}$ Mugen nonahikotasunari buruz hitz egiteak ez du esan nahi dena muga denik, ezta mugek bere iragatean dena zeharkatzen dutenik ere; hobe da "presentzia espektral» gisa ulertzea (Mendiola, 2019: 43), mehatxu ezkutu bat, edozein unetan ager daitekeena eta subjektuak atzitu dezakeena, migranteen presentziaren legezkotasunik ezari buruzko etengabeko oroigarri gisa, hauei dakarkien subjektibazio- eta diziplinamenduefektuekin.
} 
sinatutako akordioan ikus dezakegu, Greziako uharteetara irregularki iritsitako errefuxiatu guztiak itzultzeko, diru-kopuru handi baten truke (dagoeneko 6.000 milioi euro).

Mugako kontrol-barneratzeari dagokionez, adibide gisa barne-segurtasuna indartzeko eta terrorismoaren aurka borrokatzeko Frantziako Lege berria aipa dezakegu. "Araudi berriak mugan nortasuna 12 orduz (lehen 6 ordu) egiaztatzea ahalbidetzen du eta kontrola 373 trenbide-geltokiren, porturen eta aireporturen inguruetara zabaltzen du, baita mugako 118 puntuetatik 20 kilometroko erradioaren barrura ere» (Barbero eta Donadio 2019: 149). Baina adibiderik paradigmatikoena, zalantzarik gabe, Australiako muga da. Herrialde horretako gobernuak «zatiketa-eremu» bat sortu zuen 2001 ean, Australiako kostaldean kokatua, non asilo-eskubidea indarrik gaben utzi zen, berrikuspen judizialerako eta Australiako immigrazio-legearen babesa eskatzeko aukera ezabatuz. 2013an, zatiketaeremu hori Australiako lurralde kontinental osora zabaldu zen, lurralde osoa muga bihurtuz (Shachar 2020: 41-44).

Hitz batean, migrazio-esperientzia bidaia hasi baino askoz lehenago barreiatzen den eta denboran mugarik gabe luzatzen den prozesua bihurtzen da. Kontrol horien berezitasuna ez datza espazioaren eta denboraren luzapenean, baizik eta legezko salbuespenaren betikotzean, etorkin irregularrek ez baitituzte gainerako biztanleei aitortzen zaizkien eskubide eta berme prozesalak. Horrela, lurraldean baimenik gabe dauden etorkinak mugan harrapatuak izan balira bezala tratatzen dira, muga inoiz zeharkatu izan ez balute bezala, horrek dakartzan lermekin, prozedura-berme eta segurtasun juridikoei dagokienean.

\section{MUGEN FUNTZIOAK}

Muga kontzeptuaren eta haren bilakaera historikoa eta egungo forma errepasatu ondoren - ezinezkoa baita hura ulertzea egungo zein iraganeko morfologiak kontuan hartu gabe-, haren esanahia ulertzeko modurik onena, ziurrenik, betetzen dituen funtzioen azterketaren bidez izango da. Bada, Zapata-Barrerok (2012: 45) dioenez, «mugaren kontzeptua bera kontzeptu funtzionala da. Hau da, ezin dugu kontzeptua definitu izendatzen duen funtzioa deskribatu gabe». Ildo horretatik, gaur egun hiru funtzio nagusi bereiz daitezke (ikus hurrengo irudia): lurralde-mugapearen funtzio juridiko-politiko tradizionala, funtzio sinboliko-analitikoa eta fluxu erregulazio funtzioa (ondasun-, pertsona- eta kapital-fluxuak). Hiru horiei laugarren bat gehitu beharko litzaieke: aukerak espazialki xedatzea, aurrerago ikusiko duguna.

Ikuspuntu juridiko-politiko batetik, mugak demarkazio-lineak dira, politikoki independenteak diren lurralde-erakundeak mugatzen dituztenak eta, beraz, jurisdikzio-eremu ezberdinak bereizten dituztenak. Hau da, mugek «estatu batek bere jurisdikzioaz, subiranotasunez edo ahal gorenaz legitimoki baliatu daitekeen lurraldea adierazten dute» (Velasco, 2016: 83). 
1. irudia. Mugen funtzioak

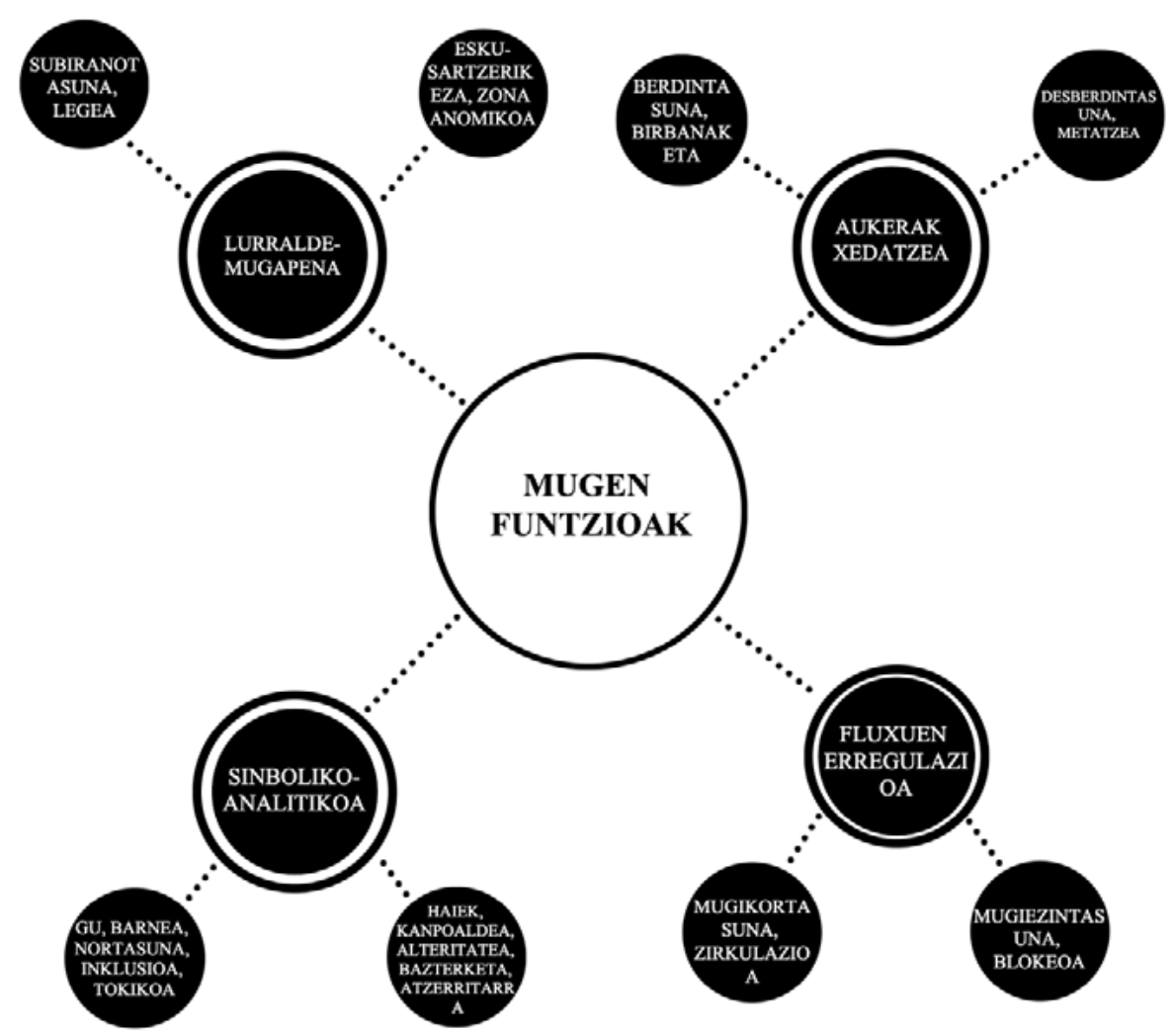

Iturria: egileak landua.

\subsection{Funtzio juridiko-politikoa}

Mugak estuki lotuta daude lurraldetasun eta estatu kontzeptuekin. Lehenengoa, norbanako edo talde batek eremu geografiko jakin baten, hau da, lurralde baten gaineko kontrola ezartzeko egiten duen ahaleginari deritzo (Cairo Carou, 2001: 31). Lurraldeak eta lurraldetasunak boterea eta kontrolarekin zerikusi handia dute, alegia, lehenengoek bigarrenak ezartzeko eta egikaritzeko euskarri gisa balio dute. Lurraldetasunak aukera ematen die gizakiei espazio bat menderatzeko ez ezik, esanahiz hornitzeko ere. Lurraldearen kontrola gaur egun mugaketarekin, mugak ezartzearekin erlazionatzen bada ere, hori ez da izan gizakiek historikoki botere politikoa erabili duten modu bakarra. Lurraldetasun-moduak nabarmen aldatu dira denboran eta tokian zehar, mugatze (fronterización) praktika anitzei bide emanez, linea zehatzen mugapetik trantsizio-eremu zabalen erakundera (Diener eta Hagen, 2012: 4-6).

Bigarren kontzeptuari dagokionez, esan daiteke estatuak eta mugak elkarren osagarri direla, eta, beraz, baten existentziak bestearena eskatzen duela (Zapata-Barrero, 2012: 52). Izan ere, estatuaren ideiak berak lurralde bat (eremu mugatu bat) dakar berarekin, botere politikoa hedatua dagoen eremua. Estatuen egungo forma politikoak eta mugak ulertzeko modua Westfaliako Itunetik (1648) datozte. Itun horretan, gaur egungo estatuen oinarriak ezarri ziren, eta beste estatu batzuen gaietan esku-hartzerik ezaren eta subiranotasunaren printzipioak ezarri. 
Hala eta guztiz ere, ez genuke mugen irudi erredukzionistarik aurkeztu nahi mugape eta lurralde-banaketaren lerro huts gisa. Horretarako ezinbestekoa da hurrengo bi dimentsioak edo funtzioak kontuan hartzea.

\subsection{Funtzio sinboliko-analitikoa}

Mugak funtzio analitiko argia betetzen du: bi unitate (gutxienez) mugatu eta bereiztea ${ }^{6}$. Sailkatze-lan sinple honek inplikazio kognitibo izugarriak ditu, lehenago ikusi dugun bezala, inguratzen gaituen mundua atzematea eta zentzua ematea ahalbidetzen diguna baita. Ideia honek are inplikazio handiagoak izango lituzke lurralde-mugen kasuan: bi unitate politiko mugarritu, haien lurralde eta jarraitutasun soziala hautsi eta haien arteko komunikazioa ${ }^{7}$ oztopatzen duten heinean, mugek ez dute soilik kanpoarekiko desberdintzen, baizik eta barne-identitate bat eratzen ere laguntzen dute. Beste era batera esanda, besteak baztertzen dituzten aldi berean, mugek kontzientzia kolektiboa eratzen, «gu»-a definitzen laguntzen dute.

Horren harira, mugek alteritatea zein identitatea sortzen laguntzen dute. Are gehiago, «haiek» (kanpo konstitutibo) baten ezarpena litzateke "gu» baten, identitate kolektibo baten artikulazioa ahalbidetuko lukeena. Mugek komunitate politikoak eratzen laguntzen dutela esan ohi da, baina, eutsi diogun bezala, gizarte-produktu bat baldin badira, logikoa izango litzateke pentsatzea mugak komunitate politikoetatik datozela, eta ez alderantziz. Argitzen zaila den galdera bat da, eta hobe litzateke norabide bikoitzeko harreman gisa ulertzea, non «mugak identitate kolektibo ezberdinen eraketan laguntzen duten, eta, era berean, komunitate politikoek mugak ezartzen dituzten» (Newman, 2002: 125).

Hala ere, barrualdearen eta kanpoaldearen, inklusioaren eta bazterketaren arteko bereizketa dikotomiko horrek ahalmen kognitibo eta heuristiko handiak baditu ere, ez da nahikoa mugen fenomenoa ulertzeko. Ikusi dugun bezala, muga-lerroa birdimentsionatzen ari da (barrualderantz tolestuz eta kanpoalderantz destolestuz); eta horrek bi espazio horien gainezarpena dakar. Bestalde, inklusioa/bazterketa logika bitar klasikoa desagertu ez bada ere, gero eta indar handiagoa hartzen ari da beste logika bat, inklusio baztertzaile edo asimetrikotzat jo genezakeena. Izan ere, immigrantea lan-merkatu informalean sartzea onartzen da, baina beste esparru batzuetatik kanpo uzten da, hala nola arlo sozial, politiko edo legaletik. Horren guztiaren helburua lan-indar esaneko eta otzana sortzea izango litzateke, babes juridiko eta asistentziala ukatzen zaiona, bai eta bere eskaerak politikoki defendatzeko gaitasuna ere.

\footnotetext{
${ }^{6}$ Zapata-Barrerok (2012) bigarren funtzioaz (bereiztu) bakarrik hitz egiten du, ziurrenik lehenengoa bigarrenean inplizitua dagoela ulertuta.

${ }^{7}$ Artikulu osoan zehar defendatu dugun bezala, bereizketa ez da mugen funtzio bakarra, baina kasu honetan metodo heuristiko gisa balio digu.
} 
Mugen funtzio sinbolikoak, hau da, espazioa (fisikoa eta soziala) banatuz eta jarraikortasuna apurtuz identitate partekatu zein desberdindu baten sorrerari laguntzen dionak, ondorio are handiagoak ditu harresien kasuan. Kasu honetan, efektu materialak bistara ateratzen badira ere, harresien efektu sinbolikoek nabarmen gainditzen dituzte lehenengoak (Brown, 2015: 57-58). Harresia ez da hesi fisiko bat bakarrik, bai eta hesi psikologiko bat ere, gotorleku baten irudi kontsolagarria eskaintzen diguna, gure segurtasunari eta bizimoduari mehatxu egiten diotenengandik salbu mantenduz. Praktikan, haren garrantzia ez dago migrazio-fluxuak atxikitzeko eraginkortasunean (gutxitan lortzen dutena gainera) oinarrituta, baizik eta ondorio performatiboetan.

Brownek (2015) «antzezpenak», «dramatizazioak» eta «itxitura ikonografikoak» direla dio, masa dudatsu (globalizazioagatik eta haren dinamika eta ondorioengatik larrituta dagoena) batzuen autokontsumorako eraikitzen direnak. Horrela, arreta barneko arazoetatik desbideratu eta kanpoko arazoetara proiektatzea lortzen da, zehazkiago, migratzaileengana. Hormak, beraz, «bestearen irudi antropomorfoa ezbehar nazionalen kausa gisa proiektatu daitekeen pantaila bat» ${ }^{8}$ lirateke (Brown, 2015: 170). Gizarte hauen arazoentzako erremedio eraginkor bat baino, horiei emandako errai-erantzuna da, analgesiko auto-erakargarri hutsa eta plazebo efektu argia duena. Hala ere, nahiz eta irudi lasaigarria eskaini eta epe laburrean segurtasuna eman, hormek gure segurtasun eza areagotzen dute eta bestearen, atzerritarraren, aurkako intolerantzia eta gutxiespena elikatzen dute (Valhondo de la Luz, 2010: 134).

Azkenik, garrantzitsua da aipatzea mugak ez direla mapako lerroetara soilik mugatzen, baizik eta, forma espezifikorik hartu gabe (muga «ikusezinak»), eremu askotan (juridikoadministratibo, sozial, lan-eremu, kultural eta politikoan) agertzen dira, eta etorkinen zinezko integrazioa eta haien eguneroko jarduna oztopatzen dute. Oztopo sinboliko horiek desberdintasun sozioekonomiko sakonetan gauzatzen dira; legezko estatusaren edo egonaldiaren arabera zerbitzuetarako eta eskubideetarako sarbide diferentziala ezartzen duten araudi eta erregulazioen bidez ofizializatzen edo instituzionalizatzen dira; baina, batez ere, arlo sozialean eta migratzaileen eguneroko bizitzan — metaforikoki- eraikitzen dira. Azken hauek agerian geratzen dira muga aspaldi zeharkatu duen etorkin batek, lurraldean bizitzen urteak daramatzan arren, herritarren gaitzespenarekin topo egiten jarraitzen duenean.

\subsection{Fluxuen erregulazio funtzioa}

Globalizazio-prozesuen ondorioz, mugak lekuz aldatu dira. Hori dela eta, bere ohiko rola lausotu egin da, eta jurisdikzio-muga eta aduana-hesi izatetik migrazio-fluxuen kontrol funtzio bihurtu da. Izan ere, jada aipatu dugun bezala, ondasunen, kapitalen eta informa-

8 «Una pantalla en la que puede proyectarse la figura antropomorfa del otro como causa de los infortunios nacionales». 
zioaren mugimendurako oztopoak desagertzen ari diren bitartean, pertsonen mugitzeko askatasunerako oztopoak ugaritzen ari dira. Hala ere, ez litzateke zuzena izango mugak mugimendu askerako eta trukerako oztopo huts gisa ulertzea, fluxuen erregulazioan eta kontrolean funtzio askoz konplexuagoa betetzen baitute: «mugak, fluxu globalak blokeatzeko edo oztopatzeko baino, horiek artikulatzeko funtsezko gailu bihurtu dira» (Mezzadra eta Neilson, 2017: 21).

Mugak ez dira euste-gailu soila. Aitzitik, mugikortasunaren eta kontrolaren arteko oreka bilatzen saiatzen dira ${ }^{9}$ " "Mugikortasunaren gobernu-teknologia» bihurtu dira (Mendiola, 2019: 53); fluxuak hautatuz eta iragaziz, segurtasuna arriskuan jarri gabe, arintasuna lortzen saiatzen direnak. «Mugaren funtzionalitate selektiboak mugikortasuna segmentatzea du helburu, gobernagarri izan dadin» (San Martin Seguro, 2019: 32). Aukeratze hori egiteko, informazio-bolumen handiak erregistratu eta prozesatzen dira, arrisku-profilak egin ahal izateko eta, horietan oinarrituta, erabakia hartu ahal izateko. Horixe da Frontex-en (Mugen eta Kostaldeen Guardiaren Europako Agentzia) kasua, pertsonak zaintzeko infor-

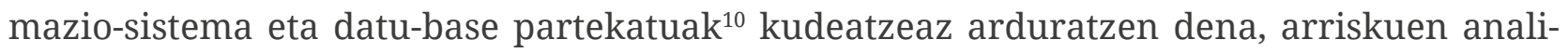
siaren ikuspegitik (Amilhat Szary, 2015: 94).

Arriskuen kudeaketan jartzen ari den gero eta enfasi handiagoa ezin da diskurtso sekuritario hauetatik kanpo ulertu; izan ere, etorkinak mehatxu gisa aurkezten dituzten diskurtso horiek berek eragin handia dute arriskuaren ebaluazioan eta estimazioan, eta hortaz, mugak irekitzeko edo ixteko erabakian. Horrela, azkenean, gurpil zoro bat sortzen da, non diskurtso xenofoboa eta mugen irrika elkar elikatzen diren, (xeno)fobia eta segurtasun ezak mugen kontrol handiagoa eskatzen duten, eta, aldi berean, hauek ezezagunarekiko beldur hori pizten duten.

Bestalde, ikuspegi marxista batetik, mugak ordena kapitalista eusteko (Guerrero, 2018: 148) eta lanaren banaketa globala erreproduzitzeko (Zamora, 2020: 60) oinarrizko tresnak izango lirateke. Ikuspegi horretatik, mugako kontrol-sistemak «kapital transnazionalaren logikaren» menpe egongo lirateke (Velasco, 2020a: 39), eta eskulan merkea bermatzeko eta hornitzeko funtsezko tresnak izango lirateke. Testuinguru horretan, «agiririk gabeko etorkina langile mota ideala bihurtu da kapitalismo neoliberalaren barruan: beti erabilgarri, gizarte-segurantzako kosturik gabe, ekonomiaren erabakimenen mende eta bere eskubideak politikoki ahoskatzeko gaitasunik gabe» (Zamora, 2020: 62).

Egile beraren ustez (Zamora, 2020: 57), mugen bidezko espazioaren banaketa kapitalismoaren sine qua non baldintza da («mugarik gabeko kapitalismoa oximoron bat da»), he-

\footnotetext{
${ }^{9}$ EBk erronka bikoitza du aurrean: «Hirugarren herrialdeetako nazionalen migrazio-fluxuak eta -mugimenduak kanpoko mugetan modu eraginkorrean nola gainbegiratu [...]; eta muga-pasabideak gehiengo bidaiari erregularrentzat, hau da, sarrera-baldintza guztiak betetzen dituztenentzat arinak eta errazak direla nola bermatu». Fronteras inteligentes: opciones y camino a seguir, COM (2011) 680, 2011ko urriaren 25ekoa.

${ }^{10}$ Hona hemen adibide batzuk: EURODAC fitxategia, Second Generation Schengen Information System (SIS II), Entry/Exit System (EES), European Travel Information and Authorization System (ETIAS), Visa Information System (VIS) eta Frontex Risk Analysis Network (FRAN).
} 
dapen- eta metatze-prozesu kapitalista amaigabean ekoizpen indar merke berrien etengabeko eransketa ahalbidetzen duena. Horrela, bere funtzio nagusietako bat eskulan merkeko gerakina sortzea izango litzateke, lan-kostu baxuei eustea ahalbidetuko lukeena. Beraz, iragazteko funtzio hori logika bikoitz bati zor zaio: alde batetik, arriskuaren logika aktuariala, segurtasuna eta arintasuna bateragarri egiten saiatzen dena, eta, bestetik, logika neoliberala, eskulan otzana eta merkea hornitzea ahalbidetzen duena.

Laburbilduz, muga dispositibo botere sinboliko-sekuritario gisa uler daiteke, jakintza, praktika eta baliabide tekniko-polizial eta legal multzo batez osatua, bere adierazpen ugarietan eta intentsitate desberdinekin lurraldean eta subjektuetan azaltzen dena, arriskuaren logika aktuarial batetik, zirkulazioa kudeatu eta iragazteko helburuarekin.

Lanaren azken zatira igaro aurretik, justizia globalaren ikuspegitik mugen berrinterpretazioari dagokiona, aipatu berri dugun fluxuen kontrol eta erregulazio funtziotik datorren azken funtzio bat azpimarratu behar dugu: bizi-aukerak espazioan mugatzea eta estatuen arteko desberdintasun ekonomikoak betikotzea (Kymlicka 2006: 66, 76-77; Ypi, 2008: 395; Sager, 2020: 5). Laugarren funtzio hau hirugarrenaren (zirkulazioaren erregulazioaren) perbertsio bat besterik ez da. Zirkulazioa continuum gisa (mugikortasuna vs. gelditasuna edo blokeoa) ulertuz gero, alde mesedegarrienean mugek zirkulazioa ahalbidetu eta erraztuko lukete, eta beste aldean, berriz, oztopatu, geldiarazi edo blokeatu egingo lukete.

Hain adiskidetsua ez den bigarren aurpegi hori harresietan, beroan eginiko itzultzeetan, etorkinen barneratzean eta abarretan islatzen da. Funtzio hori, hurrengo atalean xehetasun handiagoz garatuko dena, guztien artean boteretsuena eta maltzurrena da ziurrenik; pertsona batek bizitzan (faltan) izango dituen aukerak eta baliabideak hura jaio den mugaren aldearen eskuetan baitaude (Kymlicka, 2006: 37). Izan ere, ez da kasualitatea oztoporik eta handienak errenta-desberdintasun nabarmenenak dituzten herrialdeen artean altxatzea, hala nola Estatu Batuak eta Mexiko edota Espainia eta Maroko banatzen dituzten hormak.

\section{MUGAK ETA JUSTIZIA GLOBALA}

Orain dela oso gutxi arte, banaketa-justiziari buruzko eztabaidak estatu-naziora mugatzen ziren, eta «ondasunen banaketaren eztabaidetan mugen kontzeptua ziurtzat jotzen zen» (Zapata-Barrero, 2012: 41). Hori, neurri handi batean, John Rawls filosofo iparramerikarraren ondareari zor zaio. Izan ere, haren justizia-printzipioak nazioko komunitateetara mugatzen ziren, eta haren arabera, immigrazioa eragiten duten arazoak bere «utopia errealistan» amaituko lirateke (Rawls, 1999: 9). Hala ere, nagusi den «nazionalismo metodologikoak ${ }^{11}$ » berezkoa duen jarrera «estatistaren» aurrean, 80ko hamarkadan zenbait au-

${ }^{11}$ Nazionalismo metodologikoa «ikuspegi epistemiko —edo, hobeto esanda distortsio kognitiboa — bat da, prozesu sozialak aztertzerako orduan estatu nazionalak oinarrizko unitatetzat hartzen dituena» (Velasco, 2012: 472), eta, beraz, bere jarduerak eta betebeharrak esparru horretara mugatzen dituena. 
tore agertu ziren (adib. Beitz, 1979; Carens, 1987), ikuspegi hori zalantzan jarri eta muga nazionaletatik haragoko justizia-betebeharrak mahaigaineratzen hasi zirenak. Horrela agertu ziren justizia globalaren teoria modernoak. Teoria hauek estatu-mailan aplikatzekoak diren banaketa-justiziaren printzipioak eskala globalean koestentsibo bihurtzeko beharra planteatzen dute.

Betebehar horiek burutzeko bi alternatiba nagusi proposatzen dira: alde batetik, muga irekien politika, estatuen arteko mugimendu-askatasuna defendatzen duena, eta, bestetik, muga-kontrolak ezartzeko estatu-diskrezionaltasuna banaketa-betebehar globalak errespetatzearen mendan jartzen duten jarrerek. Daniel Loewe-ren ustez (2012: 476), mugek zeregin bikoitza izango lukete: «aukerak mugatzen dituzte eta sarrera eragozten dute». Horrela, muga irekien proposamenak bigarren zeregina (gizabanakoei sarbidea galaraztea) zalantzan jarriko luke, eta bigarrenak, berriz, lehenengoa (aukerak mugatzea). Dena den, bi ikuspegiak ados daude funtsezko alderdi batean: herrialde oparoenek justizia globala aurrera eramateko konpentsazio-mekanismoren bat ezarri beharko lukete ${ }^{12}$.

Mugak irekitzearen aldeko argudio kosmopolita pertsonen berdintasun moralaren printzipioan oinarritzen da. Printzipio honek bizi-garapenerako beharrezkoak diren baliabideak eta aukerak eskura izateko nolabaiteko berdintasuna eskatuko luke. Gizabanakoak beren agentziari edo kontrolari ihes egiten dioten egoeren (hala nola sexua, trebetasunak, arraza edo jaioterria) aurrean erantzule ez direla adosten badugu, ez lituzkete jazoera horien ondoriorik jasan behar. Mugaren alde batean edo bestean jaiotzea ausazko eta moralki garrantzirik gabeko baldintza da (edo horrela izan beharko litzateke behintzat), familia aberats edo pobre batean, emakume edo gizon baten gorputzean, talde etniko nagusi edo minoritario batean edo gaitasun fisiko eta intelektual osoak edo murriztuak dituen batean jaiotzea den bezala.

Kondizio horiek guztiak moralki arbitrarioak eta gizabanakoei leporaezinak izan arren, guztiak ez ditugu modu berean tratatzen gaur egun: gaitasun desberdinak, sexua, familiaerrenta edo talde etnikoa gero eta garrantzi txikiagoa dute Estatuari bermatzea dagozkion eskubide eta aukeretan, baina jaiolekua faktore ikaragarri erabakigarria da oraindik biziaukerak esleitzerako orduan. Joseph Carens-ek (1986: 252) dioen moduan, «mendebaldeko demokrazia liberaletako herritartasuna pribilegio feudalaren baliokide modernoa da, bizi-aukerak izugarri hobetzen dituen estatus heredatua». Izan ere, hain handia da jaioterriak gizabanakoen bizi-ikuspegietan duen eragina, ezen «herrialde bakoitzaren barruko errenta-desberdintasunak txiki geratzen baitiren herrialdeen arteko errenta-desberdintasunekin konparatzen ditugunean». Hortaz, «gizakien arteko desberdintasun-faktore nagusia ez da sexua, arraza edo adina, baizik eta norberari mundu honetan jaiotzea tokatu zaion lekua» (Velasco, 2016: 17-18).

12 Zaila da erabakitzea —eta ez dator bat artikulu honen xedearekin- justizia globalaren betebeharrak burutzeko bi eskaintzetatik zein izango litzatekeen egokiena. Gai honi buruzko hausnarketa sakonago bat Loewe-n (2012) kontsultatu daiteke. 
Filosofia politikoa muga irekien aldekoen (case for open borders) eta bazterketa-eskubidearen aldekoen (case for limits or exclusion) arteko eztabaida sutsuaren lekuko izan da. Lehenengoen artean Joseph Carens (2013) aurkitzen dugu, immigratzeko eskubidearen ikuspegi liberal-berdintzailea defendatzen duena; era berean, Philip Cole-k (2000; Wellman eta Cole 2011) moralki arbitrariotzat eta justifikaezintzat jotzen ditu mugak; Michael Huemerek (2010) mugitzeko askatasuna prima facie eskubide gisa defendatzen du; Kukathas-ek (2014; 2021) ere mugimendu askatasunaren defentsa erabat liberala egiten du; bestalde, Abizadeh-k (2008) muga-kontrolen zilegitasuna kritikatzen du teoria demokratikotik.

Bigarren taldean, hau da, immigrazioa murrizteko zilegitasuna justifikatzen dutenen artean, Michael Walzer filosofo komunitaristaz gain (2001), Miller-ek (2014, 2016) bazterketa-eskubidearen defentsa nazionalista-liberala egiten du; Wellman-ek (2008) estatu legitimoen elkartzeko askatasuna aldarrikatzen du migrazio-kontrolak defendatzeko; eta Blake-k (2005, 2020) mugimendu-askatasuna, giza eskubidetzat hartu beharren, eskubide zibil edo politiko gisa ulertzen du, autoritate hertsatzaile baten menpe egoteagatik eskuratuko litzatekeena.

Mugak gehiago irekitzeko proposamenak erantzun sutsua jaso ohi du, neurri horrek segurtasunerako ez ezik, gure ongizate-estatuen diru-kutxa publikoetarako, nazio-identitaterako, gobernagarritasunerako, eta, oro har, demokraziarako ere ekarriko lituzkeen kalteez ohartaraziz. Hala ere, Misseri-k (2019: 44) ondo esaten duen bezala, kritika horietako askok bi premisa dudagarrietan oinarritzen dira: «bata, komunitateak entitate estankoak, aldaezinak eta unibokoak direla, eta, bestea, migratzaileak iritsi berri diren komunitatera moldatzeko ezgaituak edota pertsona erabat arrotzak direla, eta, are gehiago, zentzugabekerien defendatzaile irmoak».

Kritika horiek guztiak etorkinei sasi-interesak egoztean oinarritzen dira. Horrez gain, tokiko biztanleriaren sektore batzuen antsietateaz eta beren bizi-baldintza prekarioak galtzeko fobiaz elikatzen dira, zer esanik ez herrialde aberatsenetako herritarrek haien pribilegioak galtzeko duten errezeloaz. Hala, etikari buruzko eztabaida «pribilegioaren defentsa» bihurtzen da azkenean (Wellman eta Cole 2011: 6). Bestalde, ez dago gaizki gogora ekartzea pertsonak mugitzeko askatasuna aspalditik indarrean dagoela Europan, halaber estatu federaletan, gorago aipatutako ondorio larririk gertatu gabe.

Hala ere, badakigu mugak irekitzea ez dela aterabidea, eta akats batzuk badituela: adibidez, migratzaile behartsuenak ez direla askotan emigratzen amaitzen dutenak, ez baitituzte behar adina baliabide material, laguntza-sare, prestakuntza akademiko eta lanbidegaikuntza. Aitzitik, emigratzea lortzen duten haiek dira, hain zuzen ere, prestakuntza handiena duten pertsonak (esaterako, osasun-langileak, ingeniariak edo ikertzaileak), eta beren jatorrizko herrialdeek gehien behar dituztenak.

Hutsune batzuk izan arren, egungo mugikortasun-erregimen honek sortzen dituen kanpoefektuak arintzeko eta herrialde oparoen konplazentziari aurre egiteko modu bat izango 
litzateke. Beraz, ontzat eman ditzakegun arren «desberdintasun globalak ahalbidetzen dituzten egiturazko baldintzei aurre egiten dieten» beste konponbide batzuk (Turégano, 2012: 407), herrialde pobreenetako herritarrei bizitza duina bermatuko dien bide apropos eta eraginkorrik topatzen ez dugun bitartean, estatuek beren mugak irekitzeko betebehar morala dute.

\section{MUGAK BIRPENTSATU}

Testuan zehar, mugen ibilbide eta birkonfigurazio berriak kartografiatzen saiatu gara. Estatu-nazioen mugen ohiko linealtasun eta zurruntasunak mugatze (fronterización) forma berriei bidea eman die, lurraldean gero eta proiekzio kartografiko handiagoa bereizgarri dutenak. Mugak denboran eta espazioan aurreratzen dira, migratzaileen ibilbideei aurrea hartzeko, kontrolen de-territorializazioaren (hirugarren herrialdeetarantz) zein funtzio subiranoen pribatizazioaren (hegazkin-konpainia pribatuetarantz) bidez. Horrez gain, mugalerroko kontrola areagotu egin da, zaintzarako eta informazioa prozesatzeko baliabide teknologiko-militar sofistikatuak ezarriz, fluxuen iragazpen eta segmentazio funtzioak betetzen dutenak. Eta, azkenik, mugak lurraldean barneratzen dira barne-kontrolen ezarpenaren bidez. Espazioan sartze horrek bi ondorio zuzen ditu: batetik, muga denboran luzatzea, inoiz erabat gurutzatuko ez balitz bezala; eta, bestetik, migratzaileen legezko salbuespen-egoera luzatzea, etengabeko segurtasun juridikorik gabeko egoera batean murgilduz. Baina, epe luzera, kontrol-praktika horiek herritar guztien eskubide eta askatasunen lerma ekar dezakete.

Mugak mugikortasunaren gobernu-teknologia gisa ere definitu ditugu, guztiz iragazgaitza den gailu baten ordez. Teknifikazio gehikuntza hau logika efizientista baten ondorio da. Logika horren helburu nagusia ez litzateke pertsonen trafikoa eragoztea, baizik eta «segurtasuna eta zirkulazio-arintasuna bateratzea» (San Martín Seguro, 2019: 34). Diskurtso sekuritario honek migratzaileen kriminalizazioari dagokionez dituen inplikazio etikoak alde batera utzita, nahiko dudagarria da baliabide hauen zabaltzeak segurtasunean eta immigrazio irregularra geldiarazteko helburuan izan duen eraginkortasuna. Mugen interpretazio onberago bat mantentzen dutenei (hau da, mugak dinamika ekonomiko berriak gobernatzeko eta migrazio-fluxu handiak bideratzeko ahalegintzat jotzen dituztenei) kontrajarrita, badira deriba sekuritario hau globalizazioak askatutako indarren aurrean ezintasunaren adierazpen baldar gisa interpretatzen dutenak.

Globalizazio-prozesu horiek mugen eraldaketa ekarri dute segurtasunaren eta arriskuen kudeaketari dagokionez, eta baita haien funtzioari dagokionez ere, tradizionalki zen jurisdikzio-muga eta aduana-oztopo izatetik migrazio-fluxuen kontrola izatera pasa baita. Diskurtso berri honek ez ditu milioika migratzaile (potentzial) horien eskubide eta premiak kontuan hartzen, migratzaile pobre izate hutsagatik mehatxutzat hartu eta sistematikoki baztertuak baitira. Izan ere, egungo migrazio-jazarpenaren erregimenak Hannah Arendt-en (2006) susmagarrien eta «etsai objektiboen» arteko bereizketa gogorarazi die- 
zaguke: lehenak, haien egoera dela eta mehatxu potentzialtzat hartzen direlako (eta delitu bat egin dezaketen susmoak daudelako) atxilotzen dituzten bitartean, bigarrenek ez dute ezer egin, eta ez dago deliturik egin dezaketen susmo sendorik.

Beharrezkoa da harresiak eta mugak konponbide gisa saltzen dituen diskurtso sekuritario hegemoniko honi aurre egitea, arazoa konpondu beharrean, bestearekiko (etorkinarekiko) intolerantzia eta beldurra areagotzen baitute; eta, horren ordez, justizia globalaren balioak eta giza eskubideekiko konpromisoa lehen planoan jartzen duen diskurtso berri bat eraikitzea. Baina mugak hainbesteraino naturalizatu egin ditugu, ezen "gaur egun muga irekien ideia izugarri arraroa iruditzen baitzaigu, izugarri arriskutsua ez esatearren, nahiz eta gero eta maizago gurutzatzen ditugun» (Harvey, 2017: 302).

Mugak inguratzen dituen santutasun-aura gorabehera, hauek ez dira ez naturalagoak ez objektiboagoak osasun eremuak, barruti judizialak edo hauteskunde-barrutiak baino, nahiz eta azken hauek erakunde artifizialtzat hartzen ditugun. Esanahi unibokoa eta atenporala izan beharrean, mugak etengabe aldatzen ari dira eta, beraz, haien esanahia aldatu daiteke. «Mugak, beraz, harresi zein zubi izan daitezke. Irmo lurraldetutako (territorializado) estatu-nazioen ereduan, lehen alderdia gailentzen da» (Cairo Carou, 2001: 36), baina horrek ez du zertan horrela izan behar. Mugak, gizarte-prozesu eta giza eraikuntzak diren heinean, helburu baterako balio duten bitartekoak edo tresnak dira. Beraz, helburuak aldatuz gero, mugak ere alda daitezke. Bestela esanda, mugak birfuntzionalizatu egin daitezke, helburu bidezkoagoekin bat etorriz.

Testu honetan ez dugu mugen funtzio juridiko-politikoa zalantzan jarri nahi, lurralderako sarbidea eragozteko eginkizuna baizik (Bauböck, 2014: 517). Hau da, ez da ezabatzearen ${ }^{13}$ alde egiten, mugak irekitzearen alde baizik. Are gehiago, ez da mugen ezinbesteko, baldintzarik gabeko eta aldebakarreko zabaltzea proposatzen, baizik eta pixkanaka irekitzea, modu kontrolatu ${ }^{14}$ eta hitzartu batean (nazioz gaindiko erakunde baten bidez, esaterako).

Gaur egungo erronken irismen potentzialki globala dela eta - horien artean migrazioak gailentzen dira-, estatuarteko koordinazio eta lankidetza handiagoa beharrezkoa da. Arlo ekonomikoan gertatzen den bezala, komenigarria litzateke migrazio-fluxuak erregulatzeko agentzia bat eratzea (edo jada existitzen den Migrazioetarako Nazioarteko Erakundeari eskumen eraginkorrak eta zinezkoak ematea), fluxu horiek giza eskubideen arabera garatzen direla berma dezan. Gero eta interkonektatuagoa eta interdependenteagoa den mundu batean, migrazio-fenomenoa ikuspegi nazional hertsi batetik heltzeak ez du emaitzarik emango. Ezin dugu gaur egungo mundua duela hiru mende baino gehiagoko mapa normatibo batekin nabigatu.

\footnotetext{
${ }^{13}$ Izan ere, justizia globalaren teoriko ia bakar bat ere ez da munduan gobernu bakarra ezartzearen aldekoa. Mundu mailan estatu bakar baten ezarpenaren aurkako argudioen azterketa Loewe-n (2012: 479-480) ikus daiteke.

${ }^{14}$ Kontrolatzeak ez dakar berekin mugen zurruntasun eta zaintza handiagoa, baizik eta «irizpide zuzen eta giza irizpideen arabera ordenatzea» (Bel Adell, 2002: 9).
} 
Asmoa, beraz, mugen irekitzeak arau bihurtzea litzateke, eta a priori «egoera berezietan mugako zirkulazioa mugatzea baztertu ez arren, murrizketa horiek egoki tasatuta egon beharko lirateke, gobernuaren diskrezionalitatea eragozteko» eta salbuespen hori normaltasun bihur ez dadin (Velasco, 2020b: 176). Azken finean, teoriak ezin dio egungo baldintza eta pentsamolde nagusiei lepoa eman — «mugen politikarik kaskarrena gaur zabaldu eta bihar ixtea da» (Bel Adell, 2002: 9). Aitzitik, transakzioak egiteko prest egon behar du, baldin eta horrekin herritarren nolabaiteko konpromisoa lortzen bada, bere horizonte normatiboari uko egin gabe ${ }^{15}$.

Migrazio-politika orok politika horrek ekar ditzakeen onura eta kalte posibleen balantze arduratsua izan behar du oinarri. Printzipio gidariak gizarte-balio nagusien araberakoak izango dira neurri batean, baina bidezko, demokratiko eta liberaltzat jotzen den migraziopolitika orok, gutxienez, honako lau ardatz hauek kontuan izan beharko lituzke: (1) autogobernu demokratikoa, (2) segurtasuna, (3) banaketa-justizia eta (4) mugikortasuna ${ }^{16}$. Nahiz eta politika batzuk beste batzuk baino gehiago hurbiltzen diren lau helburu horietara (ikus hurrengo irudia), ez dago erabat argi lau ardatz hauek uztartzeko modua. Izan ere, batzuk ez dira erraz elkarrengana egokitzen, hala nola segurtasuna eta mugikortasuna edo autogobernu demokratikoa eta mugikortasuna (edo, hobeto esanda, mugarik eza). Era berean, faktore hauek mailakatzea, hau da, gatazkarik egonez gero garrantzi handiena zeinek izan beharko lukeen erabakitzea, oso zaila izango litzateke.

2. irudia. Lau aukerak: egungo muga-erregimena, mugak ezabatzea, muga irekiak eta banaketa-justizia

Autogobernu demokratikoa

Mugikortasuna

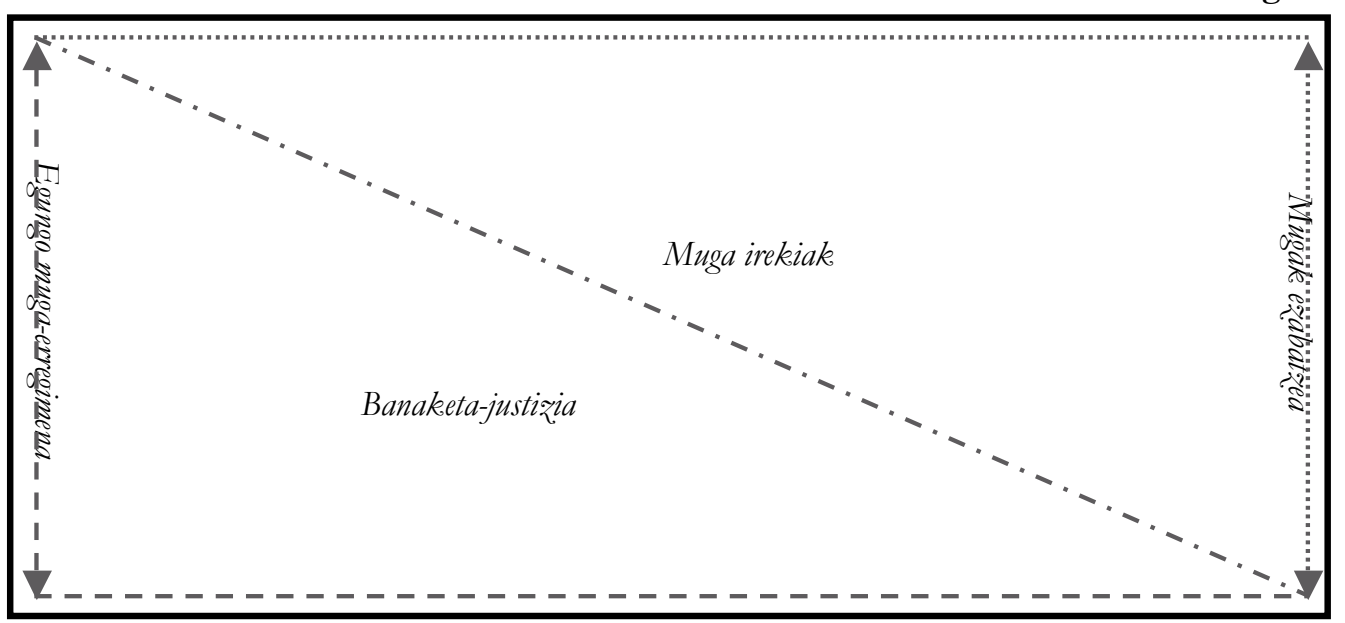

Segurtasuna

Aberastasunaren banaketa

Iturria: egileak landua.

${ }^{15}$ Horixe da Joseph Carens (2013) bere The Ethics of Immigration liburu ospetsuan egiten ahalegintzen dena.

${ }^{16}$ Printzipio hauen ordena ez da ausaz ezarri: nahiz eta lehenengoak azkenekoak baino garrantzi handiagorik ez izan - eskubideen eta askatasunen bermeari dagokionez behintzat-, lehenengoak bigarrenen ezinbesteko baldintza direla uste dugu. Izan ere, autogobernu demokratikoa bermatzen ez duen eta desgobernua sorraraz dezakeen migrazio-erregimen batek nekez berma dezake herritarren segurtasuna, eta are gutxiago banaketajustizia. Halaber, mugikortasuna, banaketa-justizia minimorik gabe, ez da posible, ekintza migratzaileak berak gutxieneko baliabide ekonomiko eta materialak eskatzen baititu. 
Dena dela, argi dago politika batzuek lau alderdi hauetan huts egiten dutela: adibidez, harresi eta muga gehiago aldarrikatzen dituen diskurtso sekuritarioak, ez baitu mugikortasuna eta segurtasuna bermatzen, eta are gutxiago banaketa-justizia. Era berean, ez dirudi mugak ezabatzearen proposamenak promestutako emaitzak (mugitzeko askatasuna eta aberastasunaren banaketa justua) ekarriko lituzkeenik; aitzitik, herrialdea desgobernu batean murgilduko luke seguru asko, gainerako helburuak betetzea eragotziz.

Egungo egoerak mugen eta, oro har, migrazio-erregimenen eginkizuna birpentsatzea eskatzen du, justizia globalaren eskakizunetara, giza eskubideen arloan hartutako konpromisoetara eta gure herrialdeek defendatzen omen dituzten gutxieneko estandar demoliberal batzuetara egokitzeko (hala nola pertsona guztien balio moral berdina, autonomia indibiduala, mugimendu-askatasuna, aukera-berdintasunaren printzipioa, elkartzeko askatasuna, estatuaren neutraltasuna eta pluraltasunaren defentsa (Fernández Manzano, 2021: 217)). Printzipio horiekin guztiekin kontsekuente izateko modu bakarra gure mugak irekitzea izango litzateke, baina ez dirudi zeregin erraza izango denik. Izan ere, inertzia historikoak, egiturazko baldintzapenak eta eratutako interesak hain dira indartsuak, ezen muga-erregimena aldatzeko edozein proposamen estatuaren subiranotasun sakrosantuaren aurkako irain gisa hartuko baita.

Mugak irekitzearen aldekoek beti hartu ohi dute frogaren karga, nahiz eta ez izan giza eskubideak sistematikoki urratzen dituen eta milioika pertsona erabateko miseriara kondenatzen dituen erregimen baten babesleak. Horregatik, arazo horri emandako erantzuna maila globalean injustiziak eta desberdintasunak erreproduzitzen dituen status quo bat den bitartean, ezin dugu mugak irekitzeko proposamena baztertu funtsagabeko premonizio katastrofista batzuen arabera. Isabel Turegano-k (2012: 407) ondo dioenez, «egokia eta eraginkorra den egitura instituzional globalik ezean, estatuek ezin diete beren justizia-betebeharrei ihes egin». Eztabaida zintzoa behar da, norberaren interesetatik harago begiratzeko gai izan gaitezen; eztabaida bat non etikaren defentsa gure pribilegioen defentsaren gainetik lehenetsiko dugun.

\section{ERREFERENTZIA BIBLIOGRAFIKOAK}

Abizadeh, A. (2008). Democratic Theory and Border Coercion: No Right to Unilaterally Control Your Own Borders. Political Theory, 36(1), 37-65. DOI: https://doi. org/10.1177/0090591707310090

Agnew, J. (1994). The territorial trap: the geographical assumtions of international relations theory. Review of International Political Economy, 1(1), 53-80. DOI: 10.1080/09692299408434268

Aguelo-Navarro, P. y Granero-Sánchez, H. V. (2017). Los muros fronterizos desde la perspectiva jurídica del ius migrandi. MODULEMA. Revista Científica sobre Diversidad Cultural, 1, 61-94. DOI: http://dx.doi.org/10.30827/modulema.v1i0.6067 
Amilhat Szary, A. L. (2015). Qu'est-ce qu'une frontière aujourd'hui? Paris: Presses Universitaires de France.

Arango, J. (2011). La «securitización» de las migraciones internacionales, diez años después. Vanguardia dossier, 41, 55-59.

Arendt, H. (2006). Los orígenes del totalitarismo. Madrid: Alianza Editorial.

Balibar, É. (2005). Violencias, identidades y civilidad: para una cultura política global. Barcelona: Gedisa.

Barbero, I. eta Donadio, G. (2019). La externalización interna de las fronteras en el control migratorio en la UE. Revista CIDOB d'Afers Internacionals, 122, 137-162. DOI: doi. org/10.24241/rcai.2019.122.2.137

Bauböck, R. (2015). Migration and the porous boundaries of democratic states. In Leibfried, S. et al., The Oxford Handbook of Transformations of the State (516531 orr.), Oxford: Oxford University Press.

Beitz, C. (1979). Political Theory and International Relations. Princeton: Princeton University Press.

Bel Adell, C. (2002). ¿Fronteras abiertas, fronteras cerradas? Papeles de Geografía, 35, 5-15.

Blake, M. (2005). Immigration. In Frey, R. G. eta Wellman C. H. (eds.), A companion to applied ethics (224-237 orr.). Malden: Blackwell Publishing Ltd.

Blake, M. (2020). Justice, Migration \& Mercy. New York: Oxford University Press.

Brown, W. (2015). Estados amurallados, soberanía en declive. Herder: Barcelona. DOI: https://doi.org/10.2307/j.ctvt9k3g2

Cairo Carou, H. (2001). Territorialidad y fronteras del estado-nación: las condiciones de la política en un mundo fragmentado. Política y sociedad, 36, 29-38.

Carens, J. (2013). The Ethics of Immigration. New York: Oxford University Press.

Carens, J. H. (1987). Aliens and Citizens: The Case for Open Borders. The Review of Politics, 49(2), 251-273. DOI: https://doi.org/10.1017/S0034670500033817

Cole, P. (2000). Philosophies of exclusion: Liberal Political Theory and Immigration. Edinburgh: Edinburgh University Press.

Debray, R. (2016). Elogio de las fronteras. Barcelona: Gedisa. 
Diener, A. C. y Hagen, J. (2012). Borders: a very short introduction. Nueva York: Oxford University Press. DOI: https://doi.org/10.1093/actrade/9780199731503.003.0001

Fernández Manzano, J. A. (2021). Liberalismo político y libertad de movimientos a escala global. Ápeiron. Estudios de filosofía, 14, 197-220.

Fernández-Carrión, M. H. (2008). Historiografía, metodología y tipología de fronteras. Naveg@mérica, 1(1).

Fernández-Jardón, F. A. (d.g.). Fronteras cambiantes, variaciones soberanas: una aproximación a la recomposición tecnológica de los dispositivos fronterizos y su proyección en la forma de estado. (Argitaratu gabeko materiala).

Foucher, M. (2012). L'obsession des frontières. Paris: Perrin.

Furedi, F. (2020). Why Borders Matter. Why Humanity Must Relearn the Art of Drawing Boundaries. New York: Routledge.

Graziano, M. (2018). What is a border? Stanford: Stanford University Press. DOI: https://doi. org/10.1515/9781503606630

Harvey, D. (2017). El cosmopolitismo y las geografías de la libertad. Madrid: Akal.

Huemer, M. (2010). Is There a Right to Immigrate? Social Theory and Practice, 36(3), 429461. DOI: $10.5840 /$ soctheorpract201036323

Kukathas, C. (2014). The Case for Open Immigration. In Cohen, A. I. eta Wellman, C. H. (eds.), Contemporary Debates in Applied Ethics (376-388 orr.). Malden: Wiley Blackwell.

Kukathas, C. (2021). Immigration and Freedom. Princeton: Princeton University Press.

Kymlicka, W. (2006). Fronteras territoriales. Madrid: Trotta.

Loewe, D. (2012). Obligaciones de justicia: ¿open borders o justicia distributiva? Arbor: Ciencia, Pensamiento y Cultura, 188(755), 475-488. DOI: https://doi.org/10.3989/ arbor.2012.755n3002

Mendiola, I. (2018). La frontera incorporada: espacio, cuerpo y seguridad. Revista Mexicana de Análisis Político y Administración Pública, VII(2), 13-32.

Mendiola, I. (2019). El despliegue fronterizo en el contexto de la Unión Europea bajo el actual ethos securitario. Revista CIDOB d'Afers Internacionals, 122, 39-60. DOI: https:// doi.org/10.24241/rcai.2019.122.2.39 
Mezzadra, S. eta Neilson, B. (2017). La frontera como método (o la multiplicación del trabajo). Madrid: Traficantes de sueños.

Miller, D. (2014). Immigration: The Case for Limits. In Cohen, A. I. eta Wellman, C. H. (eds.), Contemporary Debates in Applied Ethics (363-375 orr). Malden: Wiley Blackwell.

Miller, D. (2016). Strangers in our midst. The Political Philosophy of Immigration. Cambridge: Harvard University Press.

Misseri, L. E. (2019). La utopía de un mundo de fronteras abiertas: un argumento cosmopolita condicional en su favor. Anacronismo e Irrupción, 9(16), 40-60.

Nail, T. (2016). Theory of the border. New York: Oxforn University Press.

Newman, D. (2002). Boundaries. In Agnew, J. et al. (eds.), A Companion to Political Geography (123-137 orr.). Oxford: Blackwell.

Newman, D. (2006). The lines that continue to separate us: borders in our «borderless» world. Progress in Human Geography, 30(2), 143-161. DOI: https://doi. org/10.1191/0309132506ph599xx

Rawls, J. (1999). The Law of Peoples. Cambridge: Harvard University Press.

Sager, A. (2020). Against Borders. Why the World Needs Free Movement of People. London: Rowman \& Littlefield International.

San Martín Segura, D. (2019). Las lógicas de gobierno de lo fronterizo en el espacio Schengen: la frontera como estriación. Revista CIDOB d'Afers Internacionals, 122, 15-38. DOI: https://do i.org/10.24241/rcai.2019.122.2.15

Sassen, S. (2013). Inmigrantes y ciudadanos. Madril: Siglo XXI.

Shachar, A. (2020). The shifting border. Manchester University Press: Manchester.

Taylor, L. D. (1996). El desarrollo histórico del concepto de frontera. In Ceballos Ramírez, M. (ed.), De historia e historiografía de la frontera norte (29-55 orr.), Tamaulipas: Departamento de Fomento Editorial de la UAT.

Turégano, I. (2012). Mujeres, ciudadanía y globalización. DOXA, Cuadernos de Filosofía del Derecho, 35, 393-412. DOI: https://doi.org/10.14198/DOXA2012.35.16

Valhondo de la Luz, J. (2010). Reflexiones sobre el concepto de fronteras. ETNICEX, 1, 133145. 
Velasco, J. C. (2012). Fronteras abiertas, derechos humanos y justicia global, Arbor: Ciencia, pensamiento y cultura, 188(755), 457-473. DOI: https://doi.org/10.3989/ arbor.2012.755n3001

Velasco, J. C. (2016). El azar de las fronteras. Ciudad de México: FCE.

Velasco, J. C. (2020a). Desnaturalizando la noción de frontera en el contexto migratorio. Bajo Palabra, 23, 23-47. DOI: https://doi.org/10.15366/bp.2020.23.001

Velasco, J. C. (2020b). Desafiando el discurso securitario: La propuesta de las fronteras abiertas. In Sandoval, C. (ed.), Puentes, no muros: contribuciones para una política progresista en migraciones (163-180 orr.), Buenos Aires: CLACSO / México: Fundación Rosa Luxemburg.

Velasco, J. C. (2021). «Fronteras, muros y migraciones. Una perspectiva histórico-normativa». In F. Colom (koord.), Pasajes del pensar. Ensayos sobre filosofía, literatura y sociología en homenaje a José M. González García (229-249 orr.), Bilbao: Deusto Publicaciones de la Universidad de Deusto.

Walzer, M. (2001). Las esferas de la justicia. Mexiko Hiria: Fondo de Cultura Económica.

Wellman, C. H. (2008). Immigration and Freedom of Association. Ethics, 119(1), 109-141. DOI: https://doi.org/10.1086/592311

Wellman, C. H. eta Cole, P. (2011). Debating the ethics of immigration. Is there a right to exclude? New York: Oxford.

Wilcox, S. (2009). The Open Borders Debate on Immigration. Philosophy Compass, 4(5), 813-821. DOI: https://doi.org/10.1111/j.1747-9991.2009.00230.x

Williams, J. (2006). The Ethics of Territorial Borders. Hampshire: Palgrave Macmillan. DOI: https://doi.org/10.1057/9780230624825

Ypi, L. (2008). Justice in Migration: A Closed Borders Utopia? The Journal of Political Philosophy, 16(4), 391-418. DOI: https://doi.org/10.1111/j.1467-9760.2008.00326.x

Zamora, J. A. (2020). De la crisis migratoria a la crisis sistémica: desplazamiento forzado en la crisis terminal del capitalismo. Bajo Palabra, 23, 49-72. DOI: https://doi. org/10.15366/bp.2020.23.002

Zapata-Barrero, R. (2012). Teoría Política de la Frontera y la movilidad humana. Revista Española de Ciencia Política, 29, 29-66. 